\title{
In Vitro Direct Organogenesis Using Mature Embryo With Cotyledons In Chickpea
}

\author{
Ali Ammar ${ }^{1}$, Mahmood Ayyaz ${ }^{2 *}$, Ahsan Irshad ${ }^{3}$, Syeda Farhana Bukhari ${ }^{4,}$, Ghulam Yasin ${ }^{5}$, \\ Seema Mahmood ${ }^{5}$ and Shoaib Ur Rehman ${ }^{6}$
}

${ }^{1}$ Regional Agricultural Research Institute, 60800, Bahawalpur, Pakistan.

${ }^{2}$ Faculty of Agricultural Sciences and Technologies, Niğde University, 51240, Niğde, Turkey.

${ }^{3}$ National Centre of Space Mutagensis for Crop Improvement, Institute of Crop Sciences, Chinese Academy of Agricultural Sciences, 100081, Beijing, China.

${ }^{4}$ Department of Plant Breeding and Genetics, University College of Agriculture, Bahauddin Zakariya University, 60800, Multan, Pakistan. ${ }^{5}$ Institute of Pure and Applied Biology, Bahauddin Zakariya University, Multan, 60800, Pakistan.

${ }^{6}$ Key laboratory for crop germplasm resources and utilization, the national key facility for crop gene resources and genetic improvement, Institute of Crop Science, Chinese Academy of Agricultural Sciences, 100081, Beijing, China.

A R T I C LE IN F O

\section{Article history:}

Received 19 June 2015

Accepted 04 December 2015

Available online, ISSN: $2148-127 \mathrm{X}$

Keywords:

BAP

Chickpea

IAA

Multiple shoot regeneration

MS

Medium

${ }^{*}$ Corresponding Author:

E-mail: masarwer@gmail.com
A B S T R A C T

The present study was conducted to find out an in vitro efficient method for multiple shoot regeneration of two local chickpea varieties. The mature embryos were excised of two chickpea varieties i.e. Bittle-98 and Dasht-2000 (with cotyledon and without cotyledon) used as explants. The explants were cultured on Murashige and Skoog (MS) medium supplemented with three concentrations of $(2,3,4 \mathrm{mg} / \mathrm{l})$ 6-benzylaminopurine (BAP) using explant with and without cotyledon. Further, $0.5 \mathrm{mg} / 1 \alpha$-naphthaleneacetic acid (NAA) along with varied concentrations of BAP $(2,3,4 \mathrm{mg} / \mathrm{l})$ was also tested using explant with cotyledon. $3 \mathrm{mg} / \mathrm{l} \mathrm{BAP}$ alone and $3 \mathrm{mg} / \mathrm{l} \mathrm{BAP}$ with $0.5 \mathrm{mg} / \mathrm{l} \mathrm{NAA}$ were found the most effective cytokinin in multiple shoot induction in both tested varieties. Bittle-98 and Dasht-2000 showed $82 \%$ and $76 \%$ elongation in shoots induction with 0.2 $\mathrm{mg} / \mathrm{l}$ Indole-3-acetic acid (IAA). Root formation was recorded $80 \%$ and $60 \%$ in Bittle-98 and Dasht-2000 with $1.0 \mathrm{mg} / \mathrm{l}$ Indole-3-butyric acid (IBA). Whereas, recorded root formation was 40 and $20 \%$ in Bittle-98 and Dasht-2000 with $1.0 \mathrm{mg} / \mathrm{l} \mathrm{NAA}$. The best response for rooting observed in Bittle- 98 as its roots were thick, long and strong. Plantlets of Bittle-98 were acclimatized in solid medium for 7-14 days. The successful invitro regeneration of Bittle- 98 was observed, when excised embryo with cotyledon were used as explant, made it valuable for genetic transformation.

\section{Introduction}

Chickpea (Cicer arietinum) is an important legume with two distinct types; small seeded Desi (with brown seed coat) and large seeded Kabuli (with white seed coat) (Gaur et al., 2010). C. arietinum is main dietary constituent of food in under developing countries. The crude protein ranges from 12.4 to 31.5 percent in this crop. (Ignacimuthu and Prakash, 2006). C. arietinum plays an important role in the sustainability of rain fed agriculture system due to having ability to tolerate drought (Daryanto et al., 2015). It is a low input crop that often completes its lifecycle in drought and heat stress. It is also valued for its ability to improve the soil fertility through fixing atmospheric nitrogen (Fatima et al., 2008).

Conventional breeding methods for incorporation of resistance are often costly and time consuming and limited to lack of proper gene in gene pool (Chahal and Gosal, 2002). Recent advances in biotechnology such as plant tissue culture and genetic transformation can significantly contribute to better sustainability of this important food crop through incorporation of alien genes to develop required resistance (Somer et al., 2003). The ability to regenerate plants from cultured cells, tissues or organs constitute the basis of producing transgenic crops (Geetha et al., 1998). Tissue-culture techniques provide rapid means for vegetative plant propagation (Reinert, 1977) and also provide a method for experimentation and manipulation of plant material within the laboratory.

There are several reports available on $C$. arietinum shoot regeneration from immature or mature cotyledons (Aasim et al., 2013; Ghanti et al., 2010; Pawar et al., 2012; Tripathi et al., 2013). Embryonic axes with half portion of cotyledons was more responsive explant (Singh et al., 2002; Chakraborty et al., 2006; Paul et al., 2008; Yousefiara et al., 2008). However, cotyledonarynodes from mature seeds have been noted as most responsive for the induction of multiple shoots via organogenesis in chickpea (Sarker et al., 2005; Sujatha et al., 2007). The present research was designed to optimize and increase regeneration under in vitro conditions using dissected half embryos with and without cotyledon explants to study the 
response of two chickpea genotypes. Multiple shooting, elongation, rooting and acclimatization of plantlets were also investigated.

\section{Materials and Methods}

Seeds of $C$. arietinum were obtained from Pulses Program, Crop Science Institute NARC, Islamabad, Pakistan. The seeds of two chickpea varieties (Bittle-98 and Dasht, 2000) were used as explants source. Two types of explants i.e. embryonic axes with endosperm and without endosperm were tested for their in vitro regeneration response. These seeds were surface-sterilized with $70 \%$ ethanol for one minute and with $40 \%$ chlorex for 20 minutes followed by 4-5 washing with sterilized $\mathrm{dH}_{2} \mathrm{O}$. Surface sterilized seeds were soaked in sterile double distilled water for 16-18 hours. After discarding water, seeds were allowed to germinate for one day. The seed coats were removed, the radicals were discarded and a longitudinal slit was made. The dissected half embryos with and without cotyledon were chosen as explants.

\section{Multiple Shoot Induction}

Explants were cultured on MS media (Murashige and Skoog, 1962) supplemented with BAP (2, 3 and $4 \mathrm{mg} / \mathrm{l})$ and NAA $(0.5 \mathrm{mg} / \mathrm{l}), 3 \%$ sucrose and $0.8 \%$ agar. The explants were kept under a photoperiod for 16/8 hours light/dark cycle at $22 \pm 2{ }^{\circ} \mathrm{C}$. Regular sub culturing was done at 7 days intervals. Twenty four explants from each genotype in triplicate sets were cultured. Number of shoots produced from each explant was counted after 14 days.

\section{Shoot Elongation}

Explants with emerging shoots from the best regeneration medium were further cultured in medium containing IAA $(0.2,0.25$ and $0.5 \mathrm{mg} / \mathrm{l})$ for another $20-25$ days. Three replicas of 46 regenerating explants were used for each treatment.

\section{Rooting}

Five elongated shoots were transferred in semisolid medium supplemented with plant growth regulator i.e. IBA (1.0 and 0.5) and NAA (1.0, $0.5 \mathrm{mg} / \mathrm{l}), 3 \%$ sucrose and $0.5 \%$ agar for rooting. Root regeneration responses were recorded after 10 and 14 days of the culture.

\section{Acclimatization and Establishment of Plantlets}

Plantlets that developed long and strong roots were used for acclimatization. The regenerated plantlets were shifted in pots containing sand-soil-manure mixture $(1: 1: 1)$. Pots were covered with polythene bags for one week and put in to a growth chamber, in order to protect humidity and better establishment. After one week, holes were made in polythene bags and three weeks later pots were finally shifted in green house.

\section{Data Analysis}

Each of the experiment conducted thrice and single experiment was treated as one replication. Complete Randomize Design (CRD) was used as experimental design. The mean values along with standard error (SE) were calculated for all experimental treatments. Statistical differences among means were estimated at 5\% level of probability using Duncan's Multiple Range Test (DMRT) with the help of Statistical Software version 5.0 (Stat Soft, 1995).

\section{Results and Discussion}

Concentrations Impact of PGRs on Multiple Shoot Induction

Effect of BAP on explant embryos having cotyledon: The three concentrations of BAP on embryos with cotyledon showed variable results regarding multiple shoot formation between both varieties (Tables 1). The BAP treated embryo having cotyledon promoted multiple shoot formation on the both tested cultivars (Fig. 1). In cultivar Bittle-98 had maximum shoot induction 72.2 percent on MS medium containing $3 \mathrm{mg} / \mathrm{l} \mathrm{BAP}$, followed by 62.5 percent with $2 \mathrm{mg} / \mathrm{l} \mathrm{BAP}$ and 59.7 percent with 4 mg/l BAP respectively. Whereas, cultivar Dasht-2000 showed maximum shoot induction 73.6 percent with 3 $\mathrm{mg} / \mathrm{l}$ BAP, 69.2 percent with $2 \mathrm{mg} / \mathrm{l}$ BAP and 61.1 percent with $4 \mathrm{mg} / \mathrm{l}$ BAP respectively (Table 1).

Effect of BAP on explant embryos without cotyledon: The impact of tested concentrations of BAP on embryos without cotyledon for multiple shoot formation is shown (Table 2). The embryo without cotyledon promoted multiple shoot formation by the use mentioned PGRs in both tested varieties (Fig. 2). In cultivar Bittle-98 maximum shoot induction was recorded 58.3 percent on MS with $3 \mathrm{mg} / \mathrm{l}$ BAP followed by 55.5 percent with 2 $\mathrm{mg} / \mathrm{l} \mathrm{BAP}$ and 34.7 percent with $4 \mathrm{mg} / \mathrm{l}$ BAP respectively. Whereas, cultivar Dasht-2000 showed maximum shoot induction 20.8.6 percent with $3 \mathrm{mg} / \mathrm{l} \mathrm{BAP,} 16.6$ percent with $2 \mathrm{mg} / \mathrm{l} \mathrm{BAP}$ and 12.5 percent with $4 \mathrm{mg} / \mathrm{l} \mathrm{BAP}$ respectively (Table 2).

Table1 Effect of different concentrations of BAP on multiple shoot induction from half embryo along with cotyledon explants of chickpea.

\begin{tabular}{c|cccc}
\hline Plant Growth Regulator & \multicolumn{2}{|c}{ Bittle-98 } & \multicolumn{2}{c}{ Dasht-2000 } \\
\cline { 2 - 5 } Concentrations & Mean \pm SE & Percentage & Mean \pm SE & Percentage \\
\hline BAP $(2 \mathrm{mg} / \mathrm{l})$ & $15.00 \pm 0.57$ & 62.5 & $16.66 \pm 1.33$ & 69.2 \\
BAP $(3 \mathrm{mg} / \mathrm{l})$ & $17.33 \pm 0.88$ & 72.2 & $17.66 \pm 1.45$ & 73.6 \\
BAP $(4 \mathrm{mg} / \mathrm{l})$ & $14.33 \pm 0.88$ & 59.7 & $14.66 \pm 1.20$ & 61.1 \\
\hline "Means followed by the different letters indicates statistically significant differences at 5\% probability level.
\end{tabular}


Table 2 Effect of different concentrations of BAP on multiple shoot induction from half embryo without cotyledon explants of chickpea.

\begin{tabular}{c|cccc}
\hline Plant Growth Regulator & \multicolumn{2}{|c}{ Bittle-98 } & \multicolumn{2}{c}{ Dasht-2000 } \\
\cline { 2 - 5 } Concentrations & Mean \pm SE $^{*}$ & Percentage & Mean \pm SE $^{*}$ & Percentage \\
\hline BAP $(2 \mathrm{mg} / \mathrm{l})$ & $13.33 \pm 0.33 \mathrm{a}$ & 55.5 & $4 \pm 0.57 \mathrm{~b}$ & 16.6 \\
BAP $(3 \mathrm{mg} / \mathrm{l})$ & $14.00 \pm 0.57 \mathrm{a}$ & 58.3 & $5 \pm 0.57 \mathrm{a}$ & 20.8 \\
BAP $(4 \mathrm{mg} / \mathrm{l})$ & $8.33 \pm 0.66 \mathrm{~b}$ & 34.7 & $3 \pm 0.57 \mathrm{~b}$ & 12.5 \\
\hline
\end{tabular}

"Means followed by the different letters indicates statistically significant differences at $5 \%$ probability level.

Table 3 Effect of different concentrations of BAP and NAA on multiple shoot induction from half embryo along with cotyledon explants of chickpea.

\begin{tabular}{c|cccc}
\hline Plant Growth Regulator & \multicolumn{2}{|c}{ Bittle-98 } & \multicolumn{2}{c}{ Dasht-2000 } \\
\cline { 2 - 5 } Concentrations & Mean \pm SE $^{*}$ & Percentage & Mean \pm SE $^{*}$ & Percentage \\
\hline BAP+NAA $(2+0.5 \mathrm{mg} / \mathrm{l})$ & $11.00 \pm 0.66 \mathrm{~b}$ & 45.8 & $10.00 \pm 0.88 \mathrm{~b}$ & 41.6 \\
BAP+NAA $(3+0.5 \mathrm{mg} / \mathrm{l})$ & $14.00 \pm 0.57 \mathrm{a}$ & 58.3 & $12.00 \pm 1.00 \mathrm{a}$ & 50 \\
BAP+NAA $(4+0.5 \mathrm{mg} / \mathrm{l})$ & $10.00 \pm 0.88 \mathrm{~b}$ & 41.6 & $9.00 \pm 0.66 \mathrm{~b}$ & 37.5 \\
\hline
\end{tabular}

"Means followed by the different letters indicates statistically significant differences at $5 \%$ probability level

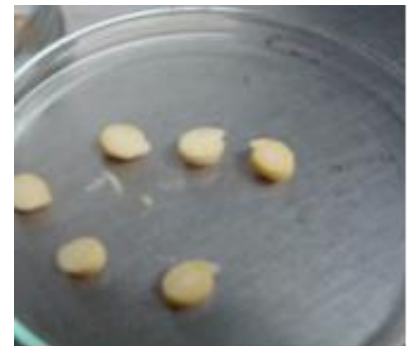

A. with cotyledon

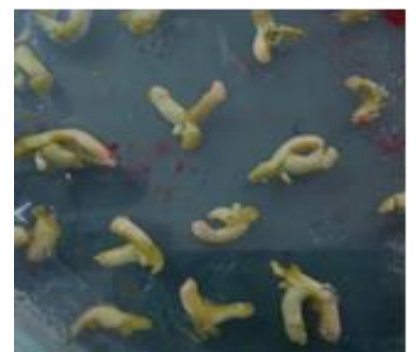

B. without cotyledon

Fig. 1 Regeneration of whole plant from half embryo explants.

Effect of BAP and NAA on explant embryos without cotyledon: The impact of NAA along with varied concentrations of BAP on embryos with cotyledon for multiple shoot formation is shown (Table 3). In cultivar Bittle-98 maximum shoot induction was recorded $58.3 \%$ on MS with $3 \mathrm{mg} / \mathrm{l} \mathrm{BAP}+0.5 \mathrm{mg} / \mathrm{l} \mathrm{NAA}$ followed by 45.8 percent with $2 \mathrm{mg} / \mathrm{l} \mathrm{BAP}+0.5 \mathrm{mg} / \mathrm{l} \mathrm{NAA}$ and 41.6 percent with $4 \mathrm{mg} / \mathrm{l} \mathrm{BAP}+0.5 \mathrm{mg} / \mathrm{l} \mathrm{NAA}$ respectively. Whereas, cultivar Dasht-2000 showed maximum shoot induction 50 percent with $3 \mathrm{mg} / \mathrm{l} \mathrm{BAP}+0.5 \mathrm{mg} / \mathrm{l} \mathrm{NAA}$, 41.6 percent with $2 \mathrm{mg} / \mathrm{l} \mathrm{BAP}+0.5 \mathrm{mg} / \mathrm{l} \mathrm{NAA}$ and 37.5 percent with $4 \mathrm{mg} / \mathrm{BAP}+0.5 \mathrm{mg} / \mathrm{l} \mathrm{NAA}$ respectively (Table 3).

Effect of all concentrations of BAP was nonsignificant in Bittle-98. Further, explants of Bittle-98 showed differences in terms of multiple shoot production. Significant differences in multiple shoot formation was recorded in Dasht-2000 to various hormonal concentrations, which indicated that there might be some indigenous plant factors residing in cotyledon necessary for promotion of multiple shoot formation. Singh et al. (2002) also reported that the presence of cotyledon attached to embryo was essential for shoot production. It can be estimated that selection of embryo with cotyledon combined with additional PGR might be served as useful explants for genetic transformation point of view. Similarly, Chakraborti et al. (2006) reported that combination of cytokinins with a relatively lower concentration of auxin was useful to have efficient frequency of multiple shoot production in Indian origin

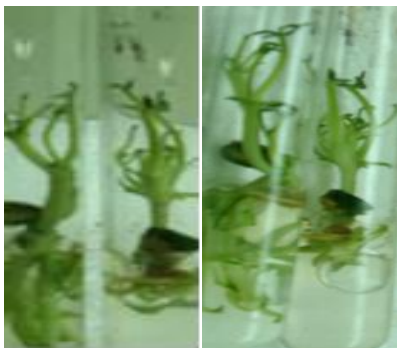

A. with cotyledon

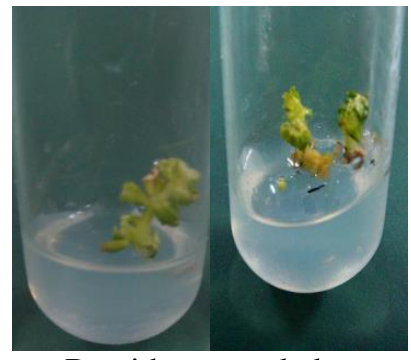

B. without cotyledon
Fig. 2 Regeneration of multiple shoots from an explants after 14 days of incubation

chickpea cultivars. Such kind of combination was also tested in the current investigation. Various concentrations of BAP (2, 3 and $4 \mathrm{mg} / \mathrm{l})$ were tested in combination with NAA $(0.5 \mathrm{mg} / \mathrm{l})$. Different concentrations of BAP along with NAA did not improve the frequency of shoot formation as compared to alone BAP concentration (Table 3). Yousefiara et al. (2008) also reported that use of BAP alone showed best response for multiple shoot induction.

Effect of IAA on elongation of shoots with cotyledon: The effect of three concentrations of IAA on elongation of shoot induction from half embryo along with cotyledon explants of chickpea (Fig. 3). It was observed that further growth of regenerated shoots was inhibited by either alone with BAP or BAP in combination with NAA. So, it was attempted to elongate shoots with selected $(0.2,0.25$ and $0.5 \mathrm{mg} / \mathrm{l})$ IAA concentrations. It was observed that IAA $0.2 \mathrm{mg} / \mathrm{l}$ was the most effective for elongation of regenerated shoots with 82 percent in Bittle-98 and $76 \%$ in Dasht-2000 cultivars respectively (Table 4).

The average elongated shoot induction in Bittle-98 and Dasht-2000 treated with IAA $0.2 \mathrm{mg} / 1$ were $(38 \pm$ $1.15)$ and $(35 \pm 1.15)$ respectively. Whereas, elongated shoot induction in Bittle-98 and Dasht-2000 treated with IAA $0.25 \mathrm{mg} / \mathrm{l}$ were $(30 \pm 1.15)$ and $(28 \pm 1.15)$ respectively. The gradual increase of IAA had negative impact and reduced the percentage of shoot elongation, as shoot induction became nil when concentration of IAA was raised to $0.49 \mathrm{mg} / \mathrm{l}$ (Table 4 ). 
Table 4 Effect of different concentrations of IAA on elongation of shoot induction from half embryo along with cotyledon explants of chickpea after 20 days.

\begin{tabular}{c|cccc}
\hline Plant Growth Regulator & \multicolumn{2}{|c}{ Bittle-98 } & \multicolumn{2}{c}{ Dasht-2000 } \\
\cline { 2 - 5 } Concentrations & Mean \pm SE $^{*}$ & Percentages & ${\text { Mean } \pm \text { SE }^{*}}^{\text {Percentages }^{*}}$ \\
\hline IAA $0.2 \mathrm{mg} / \mathrm{l}$ & $38 \pm 1.15 \mathrm{a}$ & 82 & $35 \pm 1.15 \mathrm{a}$ & 76 \\
IAA $0.25 \mathrm{mg} / \mathrm{l}$ & $30 \pm 1.15 \mathrm{~b}$ & 65 & $28 \pm 1.15 \mathrm{~b}$ & 60 \\
IAA $0.5 \mathrm{mg} / \mathrm{0}$ & 0 & 0 & 0 & 0 \\
\hline
\end{tabular}

"Means followed by the different letters indicates statistically significant differences at 5\% probability level.

Table 5 Effect of different concentrations of IBA on root formation from elongated shoots

\begin{tabular}{c|cccc}
\hline Plant Growth Regulator & \multicolumn{2}{|c}{ Bittle-98 } & \multicolumn{2}{c}{ Dasht-2000 } \\
\cline { 2 - 4 } Concentrations & Mean \pm SE $^{*}$ & Percentage & Mean \pm SE $^{*}$ & Percentage \\
\hline IBA $0.5 \mathrm{mg} / \mathrm{l}$ & $2 \pm 0.57 \mathrm{a}$ & 40 & $1 \pm 0.00 \mathrm{a}$ & 20 \\
IBA $1.0 \mathrm{mg} / \mathrm{l}$ & $4 \pm 0.57 \mathrm{~b}$ & 80 & $3 \pm 0.57 \mathrm{~b}$ & 60 \\
\hline
\end{tabular}

"Means followed by the different letters indicates statistically significant differences at 5\% probability level.

Table 6 Effect of different concentrations of NAA on root formation from elongated shoots

\begin{tabular}{c|cccc}
\hline Plant Growth Regulator & \multicolumn{2}{|c}{ Bittle-98 } & \multicolumn{2}{c}{ Dasht-2000 } \\
\cline { 2 - 5 } Concentrations & Mean \pm SE $^{*}$ & Percentage & Mean \pm SE $^{*}$ & Percentage \\
\hline NAA 0.5 mg/l & $1 \pm 0.00 \mathrm{a}$ & 20 & $1 \pm 0.00 \mathrm{a}$ & 20 \\
NAA $1.0 \mathrm{mg} / \mathrm{l}$ & $2 \pm 0.57 \mathrm{a}$ & 40 & $1 \pm 0.00 \mathrm{a}$ & 20 \\
\hline
\end{tabular}

"Means followed by the different letters indicates statistically significant differences at 5\% probability level.

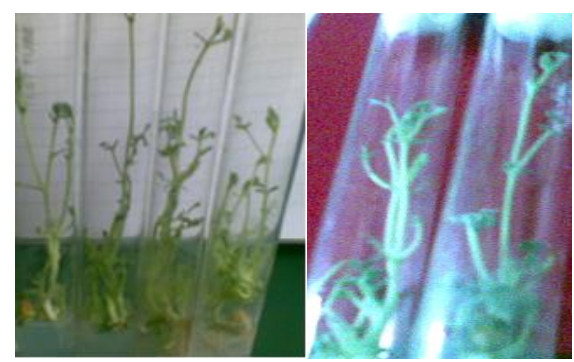

Fig. 3 Elongated shoots induction treated with IAA from half embryo with cotyledon explant after 7 days of incubation.

Concentrations impact of PGRs on Root Formation in Regenerated Shoots

Effect of IBA: The effect of tested concentrations of IBA on root formation from elongated shoots is shown (Fig. 4).In order to get full plant recovery, shoot $(3-5 \mathrm{~cm})$ were obtained after 20 days of incubation in elongated media and shifted in rooting media containing full strength of MS, $0.5 \%$ agar and IBA. Two concentrations of IBA $(0.5$ and $1.0 \mathrm{mg} / \mathrm{l})$ were used. The cultivars Bittle98 and Dasht-2000 showed best response with $80 \%$ and $60 \%$ root formation when treated with $1 \mathrm{mg} / \mathrm{l}$ IBA respectively. The present results are agreement with Aasim et al., (2013b) and Barpete et al., (2014). They observed that IBA is the most responsive growth regulator during the rooting of chickpea and Grasspea. The average numbers of rooting for Bittle-98 and Dasht-2000 were (4 $\pm 0.577)$ and $(3 \pm 0.577)$ respectively. Whereas, less promising results in favoring roots formation were recorded when $0.5 \mathrm{mg} / \mathrm{l} \mathrm{IBA}$ was used resulting 40 and 20 percent root formation in Bittle-98 and Dasht-2000 respectively (Table 5). Similar results were showed by Sujatha et al. (2007) and Paul et al. (2008).

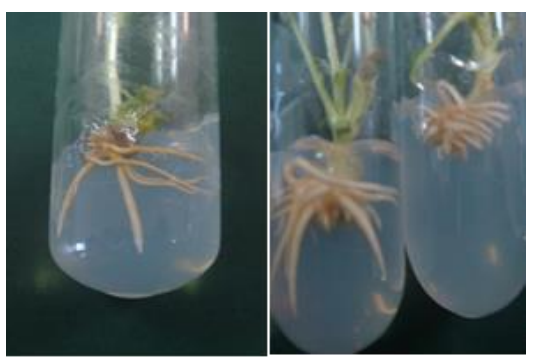

Fig. 4 Roots formation $(3-5 \mathrm{~cm})$ from elongated shoots after 10-14 days of incubation.

Effect of NAA: The effect of NAA concentrations on the root formation from elongated shoots shown in Table 6 . Two concentrations of NAA $(0.5$ and $1.0 \mathrm{mg} / \mathrm{l})$ showed that NAA have not enhanced the frequency of root formation. The mean number of root formation in Bittle98 were $(2 \pm 0.57)$ and $(1 \pm 0.00)$ in NAA $1.0 \mathrm{mg} / 1$ and NAA $0.5 \mathrm{mg} / \mathrm{l}$ respectively. Whereas, root elongation in Dasht-2000 was recorded $(1 \pm 0.00)$ when NAA was used $1.0 \mathrm{mg} / \mathrm{l}$ and $0.5 \mathrm{mg} / \mathrm{l}$ respectively.

\section{Acclimatization}

In order to study acclimatization parameters, plantlets of cultivar Bittle-98 with developed strong and long roots were used in experiments.

\section{Conclusion}

The results of present study will contribute to future studies in improvement of local chickpea cultivars. The successful culture of Bittle-98 will have a number of benefits in future. Explants excised embryo with 
cotyledon makes it a valuable for Agrobacterium tumefaction transformation point of view. It is strongly hoped that traits like insect resistance, herbicide resistance, drought tolerance which are lacking in prevailing germplasm, would be transformed into Bittle98 using our optimized protocol.

\section{References}

Aasim M, Day S, Rezaei F, Hajyzadeh M. 2013. Multiple shoots regeneration of plumular apices of chickpea. Turk. J. Agric. For., 37:33-39.

Aasim M, Day S, Rezael F, Hajyzadeh M, Mahmud ST. Ozcan, S. 2013b. In vitro shoot regeneration from preconditioned explants of chickpea (Cicer arietinum L.) cv. Gokce.. Afr. J. Biotechnol., 10: 2020-2023.

Barpete S, Khawar, KM, Ozcan S. 2014. Differential competence for in vitro adventitous rooting of grass pea (Lathyrus sativus L.). Plant Cell, Tissue and Organ Culture (PCTOC), 119: 39-50.

Chahal, GS, Gosal, SS. 2002. Principles and procedures of plant breeding: biotechnological and conventional approaches. Alpha Science Int'l Ltd.

Chakraborti D, Sarkar A, Das S. 2006. Efficient and rapid in vitro plant regeneration system for Indian cultivars of chickpea (CicerarietinumL.) Pl. Cell, Tissue and Organ Culture, 86: 117123.

Daryanto S, Wang L, Jacinthe PA. 2015. Global synthesis of drought effects on food legume production. PloS one, 10(6).

Fatima Z, Aslam M, Bano A. 2008. Chickpea nitrogen fixation increases production of subsequent wheat in rainfed system. Pak. J. Bot., 40: 369-376.

Gaur PM, Tripathi S, Gowda CLL, Ranga Rao GV, Sharma HC, Pande S, Sharma M. 2010. Chickpea Seed Production Manual. Patancheru 502 324, Andhra Pradesh, India: International Crops Research Institute for the Semi-Arid Tropics. 28 pp.

Geetha N, Venkatachalam P, Prakash V, Sita LG. 1998. High frequency induction of multiple shoots and plant regeneration from seedling explants of pigeonpea (Cajanus cajan L.). Curr. Sci., 75: 1036-1041.
Ghanti SK, Sujata KG, Rao MS, Kishor PK. 2010. Direct somatic embryogenesis and plant regeneration from immature explants of chickpea. Biologia Plantarum, 54: 121-125.

Ignacimuthu S, Prakash S. 2006. Agrobacterium mediated transformation of chickpea with $\alpha$-amylase inhibitor gene for insect resistance. J. Biol. Sci., 31: 339-345.

Murashige T, Skoog F. 1962. A revised medium for rapid growth and bioassays with tobacco tissue culture. Physiol. Pl., 15: 473497.

Paul V, Polisetty R, Chandra , Suresh K. 2008. Age of seedling explant and regeneration potential in chickpea (Cicerarietinum L.).Phytomorphol., 58: 41-48.

Pawar BD, Jadhav AS, Kale AA, Chimote VP, Pawar SV. 2012. Thidiazuron improves in vitro multiple shoot induction in chickpea (Cicer arietinum L.) cotyledon with embryonic axis. Journal of Food Legumes, 25: 9-13.

Reinert J., Bajaj, YPS. 1977. Applied and Fundamental Aspects of Plant Cell, Tissue and Organ Cultures, Springer-Verlag, Berlin (West).

Sarker RH, Tarannum F, Hoque MI. 2005. In vitro direct regeneration of three indigenous chickpea (CicerarietinumL.) varieties of Bangladesh. Pl. Tissue Cult.Biotech., 15: 135-144.

Singh R, Jat RS. Sahoo PD. 2002. Thidiazuron induced multiple shoot formation in chickpea (Cicerarietinum L). J. Pl. Biochem. Biotech., 11: 129-131.

Somers DA, Samac DA, Olhoft PM. 2003. Recent advances in legume transformation. Plant Physiol., 131: 892-899.

Stat Soft INC. 1995.Statistica for Windows (Computer program manual). Stat soft Inc., Tulsa, OK

Sujatha G, Jayabalan N, Kumari BDR. 2007. Rapid in vitro micropropagation of Cicerarietinum L. Hort. Sci., 34: 1-5.

Tripathi L, Singh AK, Singh S, Singh R, Chaudhary S, Sanyal I, Amla DV. 2013. Optimization of regeneration and Agrobacterium-mediated transformation of immature cotyledons of chickpea (Cicer arietinum L.). Plant Cell, Tissue and Organ Culture (PCTOC), 113(3), 513-527.

Yousefiara M, Bagheri A, Moshtaghi N. 2008. Optimizing regeneration condition in chickpea (Cicerarietinum L.). Pak. J. Biol. Sci., 11: 1009-1014. 